\title{
British Experience of Teacher Professionalization in Citizenship Education
}

\author{
Ke Lin \\ Faculty of Education, Beijing Normal University \\ linke@bnu.edu.cn
}

\begin{abstract}
This paper reviews British experience of inspiring and educating teachers in Citizenship Education. It is based on a case study undertaken at UCL-IOE where provides diverse and distinctive teacher training programmes. The study firstly provides an overview on the National Curriculum for Citizenship and teacher education in England. Then it introduces three types of programmes related to citizenship education at UCL-IOE, in which the author used to work as both a teaching assistant and participant researcher. By reviewing relevant documents (e.g. curriculum frameworks with teacher's guide, programme handbooks, academic literature, and participants' evaluation), the study analyses a multi-levelled structure of teacher education for citizenship at UCL-IOE, which consists of fundamental programme for concept and theory learning, specialised programme for subject and pedagogy learning both at the institute and schools, and practical programme for project-based learning cooperating with social organisations. The study further discusses how the university-led programmes could encourage and prepare teachers for their devotion into citizenship education, and argues for a comprehensive, interdisciplinary and participatory model to be implemented. The paper concludes that a high-quality teacher education for citizenship must help both pre-service and in-service teachers to develop subject-based, pedagogical and transferable competence.
\end{abstract}

\section{Keywords}

teacher professionalization - Citizenship Education - British teacher education 
Citizenship Education aims to cultivate enlightened and responsible citizens with rational and critical thinking, ethical and moral responsibility, who are able to recognise their civil, social and political rights and to participate in decisions concerning society for equality, dignity and democracy (UNESCO, 1998; Heater, 2002; Arthur et al., 2008). This is a broad area related to multiple fields of study including Social Studies, Moral Education, Character Education Peace Education, Education for Sustainable Development, Education for International and Human Rights Education. In some countries, citizenship issues has been taught in school through a specialised subject, such as Citizenship in the UK, Civics and Citizenship in Australia, Character and Citizenship in Singapore. While in others, citizenship issues have been involved in relevant subjects and study area, such as Moral and Legal Education, Ideology and Political Education in China, Social Studies in US and Religious Education in Pakistan. Due to its wide range, Citizenship Education expects for high-quality teachers who play important roles not only as academic instructors (Print \& Smith, 2001) but also as moral guides (Brimi, 2009). In multicultural societies, teachers need to promote human rights in educational practice in order to spread the ideal of justice and peace, preparing students for social and political engagement and living together democratically (Osler \& Starkey, 2010). Thus, teacher education should respond to such complex challenges and to support both pre-service and in-service teachers. This expectation leads to a question that how teacher education in Citizenship can prepare high-quality teachers. Although it is a contested question for different countries and regions, the UK, especially England, may provide a set of examples for reference, as it is one of pioneering countries in the world to implement Citizenship Education in schools and develop teacher education programmes in support of it.

This paper reports an empirical research into a British model of teacher education based on Institute of Education, University College London (UCLIOE), ${ }^{1}$ which is a specialised and outstanding institute in new teacher training and teacher professional development (TPD). The paper firstly introduces background information about Citizenship Education in England and its system for teacher training. Then, it focuses on the case of UCL-IOE where

1 UCL-IOE is a world-leading institute for research and teaching in education and social science. It has been ranked number one for education worldwide in the 2014-2019 QS World University Rankings. In 2014, it secured 'outstanding' grades from Ofsted on every criterion for its initial teacher training, across primary, secondary and further education programmes. (see also on UCL-IOE website: <https://www.ucl.ac.uk/ioe/about-ioe>). 
provides diverse teaching programmes to encourage initial teachers and to enlighten in-service teachers. The study selects three types of programme related to the subject of Citizenship, including fundamental programme, specialised programme and practical programme. As a member of teaching team, I used to work as a part-time lecturer teaching assistant and participant researcher of some programmes, so that I have taken a case study approach to examine how teachers and student teachers could be trained through the programmes. In the past five years, I have collected qualitative data to interpret features of the programmes. The majority of research data consist of diverse documents including policies of National Curriculum, university programme handbooks with teacher's guide, participant evaluation forms, and academic literature. Meanwhile, I have also reflected my experience that participated in course design, teaching, organisation and improving programmes. By analysing and reviewing the case programmes, the paper further presents recommendations for developing teacher education in the field of Citizenship.

\section{$2 \quad$ Understanding Citizenship Education in England}

\subsection{A Compulsory Subject}

Citizenship in England has been recognised as a compulsory school subject. The Crick Report published in 1998 was an initial and fundamental advisory document for promoting citizenship curriculum in schools. The leading author of the report who worked as the chair of an Advisory Group on Citizenship, Bernard Crick emphasised the importance of citizenship education:

Civic education is about the civic virtues and decent behaviour that adults wish to see in young people. But it is also more than this. [...] Active citizens are as political as they are moral; moral sensibility derives in part from political understanding; political apathy spawns moral apathy. (QCA, 1998, p. 10)

The report highlights three related elements of "effective education for citizenship", namely the development of students for their "social and moral responsibility, community involvement and political literacy” (QCA, 1998, p. 11).

With a significant influence of the report, Citizenship was authorised and carried out as a statutory subject in England for students at maintained secondary schools (Key Stage $3 \& 4$ ). It has been carried out to equip students with knowledge, skills and values that enable them to become informed, responsible and active citizens who contribute to their communities and enhance 
democratic society, beginning in school and then radiating out (DfEE \& QCA, 1999). Since 2002, Citizenship has stayed in National Curriculum framework for almost two decades, although it did not always earn a 'high-profile concern' especially after the economic crash of 2008 and the governing Party change of 2010 (Davies \& Chong, 2016, p. 22). It is also designed for and taught in primary school (Key Stage $1 \& 2$ ) as a non-statutory subject so that 'schools can plan a whole curriculum' (DfE, 2015, p. 1), which could be regarded as a good preparation for the statutory subject in secondary level. However, the limitation of quantity and quality of professional teachers has been concerned during the development of Citizenship curriculum (Heater, 2001; Davies \& Chong, 2016). It is obvious that the call for good teacher training and agencies is still lasting.

\subsection{A Comprehensive Study Area}

Citizenship is a comprehensive study area, which expects to equip students with key competence of good and active citizens of society and to live together locally, nationally and globally. The first National Curriculum for Citizenship in England was jointly published by Department for Education and Employment (DfEE) and Qualifications and Curriculum Authority (QCA) in 1999 and put into implementation in 2002, which addressed the importance of the subject:

Citizenship gives pupils the knowledge, skills and understanding to play an effective role in society at local, national and international levels. It helps them to become informed, thoughtful and responsible citizens who are aware of their duties and rights. It promotes their spiritual,moral, social and cultural development, making them more self-confident and responsible both in and beyond the classroom. (DfEE \& QCA, 1992, p. 12)

Such an initial curriculum framework has implied the multiple tasks undertaken by citizenship education, which refers to learning contents in three levels (local, national and international) and four aspects (spiritual, moral, social and cultural). The focus of the tasks has been divided into three pedagogical dimensions: knowledge about "becoming informed citizens", skills of "enquiry and communication", and skills of "participation and responsible action" (p. 6). Teachers are required to undertake these tasks in their course plan and teaching practice.

The Qualifications and Curriculum Authority led the improvement of the National Curriculum between 2002 and 2010, which carried out the updated National Curriculum for Citizenship published in 2007. This version of framework explicitly highlighted three pair of key concepts for study: democracy and 
justice, rights and responsibilities, identity and diversity. It also continuously emphasised the development of enquiry, communication and participation skills, rephrased as three key processes: critical thinking and enquiry, advocacy and representation, participation and taking informed and responsible action (QCA, 2007a, 2007b). During this round of curriculum implementation, different stakeholders (e.g. policy advisers, policy makers, academics, teachers, young people, schools, NGOs, Ofsted) cooperated together to develop better researchbased teaching and teacher training programmes. For example, The National Foundation for Educational Research (NFER) kept funding and appointing researchers to undertook eight longitudinal study to track the significant progress and challenges of citizenship education in secondary schools (Kerr et al., 2003; Kerr et al., 2004; Cleaver et al., 2005; Ireland et al., 2006; Kerr et al., 2007; Benton et al., 2008; Keating et al., 2009; Keating et al., 2010). The Association for Citizenship Teaching working with schools and NGOs, have provided training programmes, membership services and networking opportunities to promote citizenship education.

After the Conservative Party took over the government power in 2010, a new revised National Curriculum for Citizenship was drafted in 2013 and formally implemented in 2014, which is the most recent version of curriculum framework. It has reaffirmed the significance of high-quality citizenship education that prepares students with knowledge and awareness of democracy, government and laws. The new curriculum increases the weight on critical-thinking skills and financial management skills.

Teaching should equip pupils with the skills and knowledge to explore political and social issues critically, to weigh evidence, debate and make reasoned arguments. It should also prepare pupils to take their place in society as responsible citizens, manage their money well and make sound financial decisions. (DfE, 2013, p. 1)

In order to understand the curriculum change in detail, I have summarised the suggested learning contents in three main versions of curriculum programme respectively published in 1999, 2007 and 2013, and made a brief comparison among them (see Table 1).

The table illustrates a rise-and-fall tendency in National Curriculum for Citizenship, which can be directly seen from the decreasing volume of curriculum documents and learning contents. To nurture 'responsible' citizens of the United Kingdom, the new curriculum stresses understanding of 'political system of democratic government', 'monarch' and 'Parliament' and 'laws and 
TABLE 1 Suggested contents of teaching in citizenship national curriculum in England

\begin{tabular}{llcl}
\hline $\begin{array}{l}\text { Published } \\
\text { year }\end{array}$ & 2009 & 2013 \\
Pedagogical & & \\
element & & \\
\end{tabular}

\begin{tabular}{|c|c|c|c|}
\hline Knowledge & $\begin{array}{l}\text { - issues about fairness, } \\
\text { social justice, respect } \\
\text { for democracy, right } \\
\text { and wrong, rights and } \\
\text { obligations in society, } \\
\text { and diversity at school, } \\
\text { local, national and } \\
\text { global level; } \\
\text { - topical political, } \\
\text { spiritual, moral, social } \\
\text { and cultural issues, } \\
\text { problems and events; } \\
\text { - the role of the legal, } \\
\text { political,religious, } \\
\text { social, constitutional } \\
\text { and economic } \\
\text { institutions and } \\
\text { systems that } \\
\text { influence their lives } \\
\text { and communities. }\end{array}$ & $\begin{array}{l}\text { - political, legal and } \\
\text { human rights, and } \\
\text { responsibilities of } \\
\text { citizens; } \\
\text { - the roles of the law } \\
\text { and the justice system; } \\
\text { - parliamentary } \\
\text { democracy, } \\
\text { government within } \\
\text { UK and other forms of } \\
\text { government; } \\
\text { - the development of, } \\
\text { and struggle for, } \\
\text { different kinds of rights } \\
\text { and freedoms (speech, } \\
\text { opinion, association } \\
\text { and the vote); } \\
\text { - the ways of } \\
\text { public economic } \\
\text { decision-making, }\end{array}$ & $\begin{array}{l}\text { - a sound knowledge of } \\
\text { how the UK is governed, } \\
\text { its political system } \\
\text { (e.g. Parliament and the } \\
\text { monarch,voting and } \\
\text { elections, political } \\
\text { parties) and how citizens } \\
\text { participate actively in its } \\
\text { democratic systems of } \\
\text { government; } \\
\text { - the nature of rules and } \\
\text { law, the justice system } \\
\text { (e.g. the role of the } \\
\text { police, courts and } \\
\text { tribunals) and how laws } \\
\text { are shaped and enforced; } \\
\text { - other systems and forms } \\
\text { of government and laws } \\
\text { beyond the UK. }\end{array}$ \\
\hline
\end{tabular}

\begin{tabular}{|c|c|c|c|}
\hline Skills & $\begin{array}{l}\text { - seven key skills: } \\
\text { communication, } \\
\text { application of } \\
\text { number, using and } \\
\text { applying ICT, working } \\
\text { with others, taking part } \\
\text { in responsible action, } \\
\text { improving own learning } \\
\text { and performance, and } \\
\text { problem solving; }\end{array}$ & $\begin{array}{l}\text { - critical thinking and } \\
\text { enquiry (e.g. exploring } \\
\text { topical and } \\
\text { controversial issues and } \\
\text { problems, } \\
\text { undertaking research, } \\
\text { plan and enquiries, } \\
\text { analysing and } \\
\text { evaluating sources, and } \\
\text { recognising bias); }\end{array}$ & $\begin{array}{l}\text { - skills to think critically } \\
\text { and debate political } \\
\text { questions; }\end{array}$ \\
\hline
\end{tabular}




\begin{tabular}{|c|c|c|c|}
\hline $\begin{array}{l}\text { Published } \\
\text { year } \\
\text { Pedagogical } \\
\text { element }\end{array}$ & 1999 & 2007 & 2013 \\
\hline & $\begin{array}{l}\text { - five other skills: } \\
\text { thinking skills, } \\
\text { financial capability, } \\
\text { enterprise and } \\
\text { entrepreneurial skills, } \\
\text { work-related learning, } \\
\text { and education for sus- } \\
\text { tainable development; } \\
\text { - being actively } \\
\text { involved in the life of } \\
\text { their school, neigh- } \\
\text { bourhood and wider } \\
\text { communities and to } \\
\text { become more effec- } \\
\text { tive in public life. }\end{array}$ & $\begin{array}{l}\text { - advocacy and } \\
\text { representation (e.g. } \\
\text { identifying different } \\
\text { values, expressing } \\
\text { viewpoints, presenting } \\
\text { a convincing argu- } \\
\text { ment, interpreting and } \\
\text { using media and ICT } \\
\text { for informing and in- } \\
\text { fluencing the public) } \\
\text { - taking informed and } \\
\text { responsible action (e.g. } \\
\text { affecting communities } \\
\text { and the environment } \\
\text { based on research, ne- } \\
\text { gotiation, and critical } \\
\text { assessment, handling } \\
\text { disagreements and } \\
\text { conflicts) }\end{array}$ & $\begin{array}{l}\text { - participating actively } \\
\text { in school-based ac- } \\
\text { tivities, volunteering, as } \\
\text { well as other forms of } \\
\text { responsible activity; } \\
\text { - skills to manage money } \\
\text { and plan for future } \\
\text { financial needs (e.g. } \\
\text { practice of budgeting, } \\
\text { managing risk, income } \\
\text { and expenditure, credit } \\
\text { and debt, insurance, } \\
\text { savings and pensions, } \\
\text { financial products and } \\
\text { services, and under- } \\
\text { standing public fund } \\
\text { raising and spending. }\end{array}$ \\
\hline $\begin{array}{l}\text { Awareness/ } \\
\text { Values }\end{array}$ & $\begin{array}{l}\text { - meaning and } \\
\text { purpose in life and } \\
\text { differing values in } \\
\text { human society; } \\
\text { - the nature and role } \\
\text { of the different groups } \\
\text { to which they belong, } \\
\text { and promote respect } \\
\text { for diversity and } \\
\text { difference. }\end{array}$ & $\begin{array}{l}\text { - democracy and justice } \\
\text { - rights and } \\
\text { responsibilities } \\
\text { - identities and diver- } \\
\text { sity: living together in } \\
\text { the UK }\end{array}$ & $\begin{array}{l}\text { - keen awareness and } \\
\text { understanding of de- } \\
\text { mocracy, government } \\
\text { and how laws are made } \\
\text { and upheld; } \\
\text { - diverse national, } \\
\text { regional, religious and } \\
\text { ethnic identities in the } \\
\text { UK and the need for } \\
\text { mutual respect and } \\
\text { understanding. }\end{array}$ \\
\hline Source & $\begin{array}{l}\text { (DfEE \& QCA, 1999, pp. } \\
7-8,14-15)\end{array}$ & $\begin{array}{l}(\mathrm{QCA}, 2007 \mathrm{a}, \mathrm{pp} .28-32 \\
2007 \mathrm{~b}, \mathrm{pp} .42-48)\end{array}$ & (DfE, 2013, pp. 1-3) \\
\hline
\end{tabular}


the justice system' in the UK, yet limits in-depth understanding and discussion about issues of 'fairness', 'social justice', 'respect for democracy', 'right and wrong' and 'different freedoms'. It still encourages for volunteering work but focuses more on school-based activities for community improvement. Moreover, it has been found a decrease in using language of rights, freedoms, identity and diversity, active citizens and the use of media and ICT for informing and influencing public opinion, which were mentioned in previous curriculum documents, which is commented by Davies and Chong (2016) as 'a dramatic change'.

The change between the 2008 and 2014 versions was stark. The shift in emphasis away from concepts and towards things that students should know and do (understand political and legal systems, volunteer and manage their money) seemed less like a professionally formed educational programme and more like a selection of perceived current political priorities. (Davies \& Chong, 2016, p. 25)

The curriculum shift can also be read as an attempt to reinstate the national identity and reinforce Fundamental British Values. Yet, a wide practice of citizenship education is still worth the effort, beyond the tensions between individual development and community involvement, between national and global perspectives (Starkey, 2018).

In this study, not only have I noticed the recent focuses in curriculum, also paid attention to those profound and consistent issues for citizenship education. I examine in what ways and to what extent that these issues were involved in the trainning programmes for in-service and pre-service teachers between 2012 and 2017.

\subsection{Interdisciplinary and Participatory Learning Approach}

To understand citizenship education in England, it is necessary to cross beyond a subject-based perspective. It is more than an academic subject but a pragmatic field of study requiring interdisciplinary cooperation and young people's participation. The Crick Report (QCA, 1998) suggested that Citizenship can be taught through cross-curricular approaches. History, Geography and English seems to be the closest subjects to Citizenship, as they share some key skills (e.g. information-processing, reasoning, enquiry, evaluation and creative-thinking) and often collaboratively deal with controversial issues and intercultural understanding. Besides, other subjects can make valuable contributions too. 
Mathematics and Information Technology (IT) can contribute to a knowledge and understanding of electoral systems and opinion polls and the skills to get the best from them. Science and Technology subjects commonly raise ethical issues of social policy. Religious Education (RE) provides opportunities to explore moral and social concerns. Physical Education (PE) can encourage individual initiative and effort as well as teamwork skills. Modern Foreign Languages (MFL) can offer a contrasting perspective from other countries on national, European and international events and issues, while Business Studies can combine to exemplify the economic aspects of citizenship. (QCA, 1998, p. 53)

Teaching citizenship also needs participatory approaches, encouraging students to be engaged in school-based and community-based civic activities, such as School Council, volunteering and service learning, debating, election and decision-making in student groups (QCA, 1998, 2001). These approaches can help students to obtain first-hand experience of reflecting key concepts and to develop pragmatic life skills so that they gradually mature as members who "play a helpful part in the life of their schools, neighbourhoods, communities and the wider world" (DfEE \& QCA, 1999, p. 12). In other words, citizenship education could take place in the curriculum, in school culture and in community.

There is a self-evident recognition that a high-quality education needs wellqualified teachers. "What teachers know and do is one of the most important influences on what students learn" (Darling-Hammond, 1998, p. 6). Like all subjects, to fulfil the targets of Citizenship education, teacher education becomes a fundamental task that ensures the quality of teaching for which underpins effective learning in a complex and changing world, no matter at schools or in community. The Crick Report (1998) addresses that teachers have to build up relevant knowledge, understanding, skills and confidence for interactive teaching approaches in Citizenship Education. On one hand, Citizenship teachers should be trained to meet the requirements of National Standards for Qualified Teacher Status (QTS); one the other hand, they should be provided with "sufficient opportunities to experience and develop the range of knowledge, understanding and skills needed to teach citizenship" (p. 30). An ideal model of teacher education for Citizenship (TEC) should cover not 
only pedagogical skills but also profound knowledge about the subject, so that teachers are able to help students to deal with complicated problems and to learn living together in a multicultural society.

Current teacher education in England contains training for initial and inservice teacher. Table 2 shows several main programmes for teacher training.

The initial teacher training aims to help trainees to obtain Qualified Teacher Status (QTS) and degrees to become teachers. While the in-service training help teachers, who have already worked at schools, or those who want to switch to maintained schools but have not yet obtained QTs, to upgrade their degrees or to improve their professional skills (DfE, 2018). Universities and schools are

TABLE 2 Modes of citizenship teacher training in England

\begin{tabular}{|c|c|c|}
\hline & $\begin{array}{l}\text { Initial Teacher } \\
\text { Training }\end{array}$ & $\begin{array}{l}\text { In-service } \\
\text { Teacher Training }\end{array}$ \\
\hline Trainee & $\begin{array}{l}\text { - unqualified } \\
\text { teachers without } \\
\text { Bachlor degrees }\end{array}$ & $\begin{array}{l}\text { - qualified teachers } \\
\text { without postgraduate } \\
\text { degrees } \\
\text { - qualified teachers with } \\
\text { degrees }\end{array}$ \\
\hline Training Provider & $\begin{array}{l}\text { - Universities } \\
\text { - Schools }\end{array}$ & $\begin{array}{l}\text { - Universities } \\
\text { - Schools } \\
\text { - Social Organisations }\end{array}$ \\
\hline Programme & $-\mathrm{BEd}$ & $-\mathrm{PGCE}$ \\
\hline Example & $\begin{array}{l}- \text { BA } \\
- \text { BSc } \\
- \text { PGCE } \\
\text { - SCITT }\end{array}$ & $\begin{array}{l}\text { - Postgraduate Teaching } \\
\text { Apprenticeships } \\
\text { - School Direct } \\
\text { (salaried \& tuition } \\
\text { fee provided) } \\
\text { - Teach First: } \\
\text { Leadership } \\
\text { Development Programme } \\
\text { - Topic-based programmes }\end{array}$ \\
\hline Award & $\begin{array}{l}\text { - QTS } \\
\text { - Degree } \\
\text { - A scholarship or a } \\
\text { tax-free bursary }\end{array}$ & $\begin{array}{l}\text { - QTS } \\
\text { - Degree } \\
\text { - Certificate } \\
\text { - Improved skills }\end{array}$ \\
\hline
\end{tabular}


prime training providers. Most university-led programmes focus on degreebased courses helping teachers to get their Bachelor degrees which is one of basic requirements of QTS. For trainees who hope to become school teachers, Bachelor of Education (B.Ed) is very common to pursue; besides, Bachelor of Arts (BA) or Bachelor of Science (BSc) are also necessary. Some university are entitled to provide a higher level of programmes named Postgraduate Certificate in Education (PGCE) in various subjects, which help trainees to gain both QTSs and Master degrees. These programmes request for a successful completion of course learning and for a minimum of 24 weeks spent in two schools.

Some schools also have eligibility to provide training programmes to support teachers' employment and school-based professional development. For instance, 'School-Centred Initial Teacher Training (scitT)' is responsible for training and selecting new teachers. 'Postgraduate Teaching Apprenticeships' is a nationally-recognised, work-based route towards QTS. Apprentices have to successfully complete both the course and an end point assessment (EPA) after the summer to consolidate learning from initial teacher training. 'School Direct' is an employment-based route for high quality graduates, including school-led PGCE in some cases. 'Teach First' combines teacher training and leadership development together. The government of England provides a wide range of funding to encourage people to become teachers and to support inservice teachers' professional development. Trainees would have opportunity to get financial support in all three ways: tax-free bursary or scholarship (around $£ 28,000$ ), tuition fee loan and maintenance loan and additional financial support for those who are parents or have a disability (DfE, 2018). For inservice teacher trainees, they still earn salary and have possibility to get their salary increased afterwards.

In the field of Citizenship, besides university-led and school-led approaches, there are also teacher education programmes led by social and charity organisations, which provide teacher trainees with short-term courses and workshops, particular guides, training certificates and multiple resources. For example, Association for Citizenship Teaching (ACT), ${ }^{2}$ a registered charity serving Citizenship teachers and professionals, has developed a wide range of modules to support the training for teaching citizenship. Citizenship Foundation alone with its umbrella organisation Young Citizens ${ }^{3}$ focuses on building experienced team of professionals and expanding network of consultants. This kind of training programmes are usually held in a short term and cover specific topics for teaching, such as British values, anti-bullying, valuing diversity, the

2 See ACT website: <https://www.teachingcitizenship.org.uk/home>.

3 See Young Citizenship website: $<$ https://www.youngcitizens.org $>$. 
spiritual, moral, social and cultural learning, storytelling, sensitive and Controversial Issues, and character education. The organisation-led programmes work as a down-to-earth supplement to regular university-led and schoolbased teacher training modes.

Although teacher education for Citizenship (TEC) have been emphasised in National Curriculum policy, requested in the practice of schooling and increasingly provided by different agencies, its status quo does not satisfy stakeholders. There are a number of challenges have been reported. For instance, the absence of specialist professional training for teachers has not been satisfactorily filled up (Heater, 2001; Keating et al., 2009; Davies \& Chong, 2016). Teachers' nervousness about handling such a complex subject might provoke accusations of bias or indoctrination (Heater, 2001). Existing citizenship teaching in many schools is a 'whole-school' or cross-faculty responsibility, which means, on one hand, "all teachers are involved in delivering $\mathrm{CE}$, or can be called upon to do so"; on the other hand, "CE teaching is allocated to teachers who have time left on their timetables, rather than because of their experience, expertise, or interest" (Keating et al., 2009, pp. 41-42). A taken-for-granted assumption that everyone can teach the subject might result in a fact that no one would be responsible for it. Citizenship itself is a comprehensive field of study, but there is a lack of comprehensive, profound and interdisciplinary models of teacher training, which remains as one of key challenges in Citizenship Education (Andrews \& Mycock, 2007). Moreover, Citizenship has survived in National Curriculum but in a very different context from two decades ago (Davies \& Chong, 2016), which also causes the decline of the scale of teacher education. Responding to the challenges, a number of university, including Institute of Education, University College London (UCL-IOE), have made an effort to insist providing relevant programmes for teacher education.

University Response to Changing Citizenship: A Case Study at UCL-IOE

\subsection{Diversification The diversity of Programmes}

UCL-IOE provides diverse and distinctive programmes for teacher education. The programmes related to citizenship education do not only serve in-service teacher, but open to a wider range of participants interested in citizenship education, such as students majoring in various subjects and doing citizenship project, local policy-makers working in citizenship education, museum educators, and staffs working in NGOS. In this study, I select several case programmes for analysis and categorise them into three types, which are fundamental 
programmes providing academic understanding in citizenship studies, specialised programmes delivering subject-based knowledge and pedagogical skills, and practical programmes cooperating with schools and social organisations. I have listed key features of these programmes in Table 3 with further explanations.

Firstly, the fundamental approach can be understood as an introduction to citizenship-related theories and debates in philosophy, sociology, politics, history and education. The participants come from different backgrounds, including undergraduate students, postgraduate students, teachers and teaching assistants working at non-maintained school. Most of them have little knowledge and working experience about the subject of Citizenship. Taking the course of Education, Values and Society (Evs) as an example, it is one of three compulsory modules opening to student teachers who pursue for Bachelor of Education (B.Ed), which aims to introduce philosophical and sociological thinking to fundamental educational questions. Only when participants complete the course and get the B.Ed. degree, they can meet the entry standards of nationally accredited Qualified Teacher Status. This implies that citizenship-related knowledge has been located in a vital position in the curriculum structure at UCL-IOE. Another example is a short-term and distance-learning course, Transnational Perspectives on Democratic Education (TPDE), which was a collaborative module led by UCL-IOE, cooperating with Melbourne Graduate School of Education (Australia) and the University of Wisconsin-Madison (USA), opening to postgraduate students at these three world-leading universities in education study. This module has succeeded in delivering research-based knowledge, applying international perspectives for understanding citizenship and democratic education and strengthening cross-institutional collaboration (UCL-IOE, 2010; Drinkwater et al., 2019). The fundamental programmes might not directly deal with pedagogical issues of citizenship education, namely teaching Citizenship, but they focus on provide participants with a wider perspective to understand general education questions, key concepts and issues of citizenship.

Secondly, the specialised approach consists of modules that train teachers and educators who are closely working on citizenship education. For instance, Teaching and Learning of Citizenship and PSHEE (TL-Citizenship \& PSHEE) is a B.Ed. course aiming to "enhance and develop participants' subject and

4 PSHEE is the abbreviation for 'personal, social, health and economic education', which is a subject taught in British primary schools that deals with a person's emotional and social development. Many PSHEE issues are overlapping with or related to Citizenship so that it is also regarded as one of prerequisite courses before Citizenship in secondary schools. 
TABLE 3 UCL-IOE's case programmes in citizenship education

\begin{tabular}{|c|c|c|}
\hline $\begin{array}{l}\text { Type of } \\
\text { Programme }\end{array}$ & $\begin{array}{l}\text { Name of } \\
\text { Course }\end{array}$ & $\begin{array}{l}\text { Degree Level and } \\
\text { Training Approach }\end{array}$ \\
\hline \multirow[t]{2}{*}{ Fundamental } & $\begin{array}{l}\text { Education, Values and } \\
\text { Society (EVs) }\end{array}$ & $\begin{array}{l}\text { - B.Ed. course } \\
\text { - for pre-service \& } \\
\text { in-service teachers }\end{array}$ \\
\hline & $\begin{array}{l}\text { Transnational Perspectives } \\
\text { on Democratic Education } \\
(\mathrm{TPDE})\end{array}$ & $\begin{array}{l}\text { - Intensive face-to-face } \\
\text { course plus distance } \\
\text { learning } \\
\text { - cooperating with other } \\
\text { two world-leading } \\
\text { universities } \\
\text { - for postgraduate students }\end{array}$ \\
\hline \multirow[t]{2}{*}{ Specialised } & $\begin{array}{l}\text { Teaching and Learning of } \\
\text { Citizenship and PSHEE } \\
\text { (TL-Citizenship \& PSHEE) } \\
\text { MA Citizenship }\end{array}$ & $\begin{array}{l}\text { - B.Ed. course } \\
\text { - for pre-service \& } \\
\text { in-service teacher } \\
\text { - MA degree } \\
\text { - for Master students } \\
\text { in related areas and } \\
\text { in-service teachers }\end{array}$ \\
\hline & PGCE Citizenship & $\begin{array}{l}\text { - MA degree + QTS } \\
\text { qualification } \\
\text { - Internationally recognised } \\
\text { - for pre-service teachers } \\
\text { - university course comple- } \\
\text { tion + school placement }\end{array}$ \\
\hline Practical & $\begin{array}{l}\text { Global Citizenship } \\
\text { Programme - Active } \\
\text { Citizenship Strand } \\
\text { (GCP-ACS) }\end{array}$ & $\begin{array}{l}\text { - A two-week intensive } \\
\text { programme combining } \\
\text { lectures and students' } \\
\text { placements at NGos } \\
\text { - for undergraduates and } \\
\text { Master students } \\
\text { - not a particular teacher } \\
\text { training programme, } \\
\text { but open to those who } \\
\text { prepare to be teachers in } \\
\text { future }\end{array}$ \\
\hline
\end{tabular}


pedagogical knowledge in relevant areas, engage them in the wider education debates concerning both the existence and the purpose of Citizenship and PSHEE" (UCL-IOE, 2011, p. 2). The participants are teaching staff at community schools who have experience in teaching Citizenship or PSHEE. The completion of such a module along with other B.Ed course will help them to achieve QTS and to improve their teaching in Citizenship and its related subjects. MA Citizenship is a research-based module for Master students to "explore the key concepts involved in understanding citizenship education" and to "develop an understanding of contemporary issues and key research findings in citizenship education and related areas" (UCL-IOE, 2018a, p. 2). The module also encouraes students to apply their knowledge in practice in educational and related settings. Another case, PGCE Citizenship offers participants the opportunity to become specialist teachers of Citizenship and associated subjects, such as Government and Politics, Humanities, Social Sciences, Law and PSHE (UCL-IOE, 2018b). This programme focuses on training student teacher, providing them with both postgraduate degree and certificate of education. In a short, the specialised programmes reach to both in-service teacher and student teacher who particularly expect to teach the National Curriculum subject of Citizenship, or to promote the development of the subject. However, as I mentioned before, Citizenship education is more than a subject but a field of educational and social practice. Holding such a viewpoint, I expand the case study to unconventional training programmes which makes the third category.

The practical approach that I listed has little relation to the so-called formal teacher education, but promoting the ideas of citizenship and preparing seeded teacher and educators in future. The approach is represented by the UCL Global Citizenship Programme, which brings together students (1st and 2nd year-undergraduates and taught Master students) from whatever disciplines across UCL to explore the biggest global challenges. There are about ten strands focusing on different global citizenship issues, such as urban change, local and global disease, employability, volunteering, global environmental justice. I focus on Active Ctizenship Strand (GCP-ACS) that is a new strand since 2016, which underpins the initial ideas of nurturing 'active citizens' propsed in the Crick Report. The active citizenship was explained as 'a feeling of responsibility for the wellbeing of others and the planet and an understanding that concerted action can help to change the world' (UCL-IOE, 2016). The main focus of GCPACS is to promote awareness and understanding of 'active citizenship' through education practice. This approach takes citizenship as an interdisciplinary area that encourage students' collabrative and project-based learning. For those participants to become teachers in future, GCP-ACS encourages them to think about the connection between citizenship and their own subjects of teaching. 


\subsection{The Breadth of Citizenship Issues Involved in Programmes}

According to the changes of National Curriculum through the years, I have already summarised a number of important issues to be delivered in citizenship education shown in Table 1. Comparing them with the issues involved in UCLIOE's teacher training programmes, I find that the programme leaders and teaching staffs at UCL-IOE have paid attention to undertake citizenship-related issues, especially done fairly well in delivering key concepts in the sense of thick, active, participatory and cosmopolitan citizenship. UCL-IOE's programmes refer not only to those conservative topics, such as political and legal system of the UK, economic well-being and financial management; but to a lot of in-depth discussion on issues of rights, democracy, social justice, identity and diversity, the use of media and ICT, global citizenship, which have missed in newly revised National Curriculum framework. Evidence can be found in teaching and learning contents in following case programmes.

Evs module encourages learners (student teachers) to apply philosophical, historical and sociological thinking to discuss fundamental education issues, including definitions and purposes of education; the nature of education and learning; the values underpinning education in a democratic society; the historical changes of educational policy and organisation; the relationship between education and social justice, gender, race and class; the similarity and difference between equality and justice, autonomy and authority, values and rights; and especially children's rights in school (UCL-IOE, 2013, 2014). The module has also paid attention to discussions on some up-to-date and controversial issues, such as sex education, religious education, and environmental education.

TPDE had made an effort to explore transnational perspectives on democratic education and the distinct contribution of citizenship and human rights education by drawing on experience and scholarship from three continents. Topics of this module focus more on the core of citizenship education, namely social justice, democratic citizenship and democratic education (Drinkwater et al., 2019, p. 15). Students who participate in programme were expected to understand definitions, tensions and challenges of democratic education; the nature of citizenship; deliberation and talk in democratic education; diversity and inclusion, peace education; civil rights, human rights and the law; student voice and youth participation in a digital age; global mobility and its educational challenges (UCL-IOE, 2010, 2019). In fact, the students were involved in wider and deeper discussions on a number of profound issues, such as identity, language, conflict and peace-building, global educational policy, and democratic approaches to policy and education issues of democracy (Drinkwater et al., 2019). The programme contributors from different nations 
keep emphasising the fact and values of global mobility, diversity, and connectivity, which become increasingly common rather than an exception.

TL-Citizenship \& PSHEE have covered nineteen essential issues for teacher training in the field, including: aims of citizenship, human rights, human rights education, children's rights, international organisations and NGOs, global issues, media and media literacy, political literacy, oracy and communication, citizenship in Schools, participation, identity and diversity, citizenship and antiracism, teaching controversial issues, Every Child Matters and children's wellbeing, PSHEE in Schools, Drug, Alcohol and Tobacco Education and Sex and Relationship Education, Assessing Citizenship and PSHEE, and Professional Development for Teachers (UCL-IOE, 2011).

In PGCE Citizenship programme, many of issues as above are included and discussed in depth, but transferred into pedagogically related knowledge to help student teachers to become professional teachers. As the programme introduction addressed, participants will learn:

how to really engage students in Citizenship lessons, how to plan for compelling learning in Citizenship, how to support and challenge students to make optimum progress, how to build strong class boundaries and relationships, how to develop and utilise specialist subject knowledge, and how to plan memorable Active Citizenship projects. (UCL-IOE, 2018b)

One of tasks for students to plan and undertake Active Citizenship projects is also the key point of training in UCL-GCP-ACS programme.

The analysis on programme contents has demonstrated that UCL-IOE's teacher education has raised a great number of citizenship issues being taught in school, which aims to prepare participants with a wide range of perspectives and theories to understand the subject and the field of study, and enabled participants to know where they can find resources and intellectual support. However, these programmes has not strictly set in line with the newly revised National Curriculum for Citizenship. It is worthwhile to further discuss whether or not such all-round teacher education will enable the next generation of teachers to adapt the new political context in England, which would be another research question in next stage.

\subsection{The Combination of Multiple Pedagogical Approaches}

As I have discussed previously, citizenship education in fact requires for multiple and comprehensive skills. To what extent the future teachers could 
equip students with the key skills of 'critical thinking and enquiry', 'advocacy and representation' and 'responsible action-taking' (see Table 1)? The answer for the question depends on the extent that current student teachers are trained with the skills. In other words, it is depends on how programmes are organised and what kind of pedagogical considerations are involved in programme design. In this study, I have observed that most of UCL-IOE programmes have combined multiple pedagogical approaches, including lectures, seminars, student group work and presentations, workshop by guest speakers, which are designed for developing participants' skills in theoretical analysis, argument based on theories and evidences, reflection in relation to emerging practice in schools, critical-thinking on different resources and voices about democratic and citizenship education, and collaborative presentation and communication (UCL-IOE, 2010, 2011, 2013, 2014, 2016, 2017, 2018a, 2018b). These pedagogical approaches can also contribute to improving participants' academic achievement in the field of teaching and learning citizenship.

Meanwhile, there are more practice-driven pedagogical approaches to improving participants' teaching, cooperating and campaigning skills. For instance, the PGCE Citizenship provide students with a Professional Practice of 120-day (24-week) school placement at two schools, apart from Subject Studies and Wider Educational Studies in Citizenship. The student teachers have to be trained in a real situation of school, accumulating first-hand experience of teaching citizenship. GCP-ACS requires students to make a short video/film in group and suggests them to use social media for spreading their videos and arguments. This approach encourages students to think and apply new media and ICT to widely express ideas and find solutions for global challenges that they concern. GCP-ACS also provides students with an opportunity to work with NGOs, developing skills of strategic thinking, communication, networking and campaigning. In a word, the programmes offer the chance to develop hands-on skills, from course design and classroom management, from negotiation to presentation, from photography to film-editing.

\subsection{Students' Positive Evaluation with Enquiry}

In this case study, I have collected a small group of students' evaluation from a programme during teaching. I carefully review them to further examine effective learning in citizenship education. Taking TL-Citizenship \& PHSEE programme for example, among its 13 participants of 2011/2012 academic year, there were 8 students reporting their learning as "very effective and worthwhile", 4 students reporting "effective and worthwhile", and 1 student reporting "not very effective and worthwhile". When asked the extent to which 
course related to their own interests, 7 students reported for "very much so", 3 students for "fairly good", 2 students for "good", and 1 students for "not very much". Although this was a very small sample of participants, most of them have left positive feedbacks to the programme in terms of interesting subject, formal presentations and good tutor.

The course was very interesting and I have learnt a lot. The group discussions were invaluable. I was learning actively not just through lectures. I enjoyed taking this course (B.Ed Student A)

Very good subject and tutor. Tutor very knowledgeable about his subject (B.Ed Student B).

Students reported that they like the pedogogical approach of the course, which would benefit their professional development. They especially like group discussion. They thought this is a thinking-provoking learning method. The most impressive process is to generally realise the importance and the complexity of teaching controversial issues. Thus, they felt that they need more professional knowledge and skills.

At first I wasn't sure about this elective but eventually I found it very interesting and valuable for me personally as well as professionally (B.Ed Student C).

Discussions among students are very interesting because there are diverse ideas and opinions. This makes me feel citizenship issues are complex and controversial that need to be further thought and debated (B.Ed Student D).

Being taken out of the class to see other speakers and experts and having guest speakers (B.Ed Student E)

Engaging different opinions and guest speakers in the programme are welcomed by some students. They highlighted guest speech as one of their key benefits from the programmes. However, this may brought difficulties to other students who lack of a basic knowledge background. Apart from guest speaker, students also reported different types of hindered learning regarding to the unfamilarity to the topic, overloaded informaion and and tasks.

Anti-racism topic poorly delivered by visiting speaker (B.Ed Student F).

Not enough time and too much information (B.Ed Student G).

Extra work outside class and lack of background knowledge (B.Ed Stu$\operatorname{dent} \mathrm{H}$ ) 
The students comments have demonstrated that such teacher training programme enhances students' interest to the subject, while leads them to realised the comlex nature of the subject along with its context. The students acknowledged the importance of professional training programme, but the difficulties of learning and teaching in schools still existed. This implies that the current university-based programme of teacher education for citizenship need to be further improved. However, I have to realise the limitation a university-based trainning programme. For instance, topics for learning provided by the university might be too theoretical to be understood; some of them might be far away from participants' teaching environment and life experience; and in-service teachers might not have enough time to fully engaed in programe learning. In futher study, it is necessary to involve more sample students and their evaluation about more proagrammes so that we can further analyse the outcome of the programmes.

Implications from UCL-IOE's Case of Teacher Education in Citizenship

Considering the global context of changing citizenship and curriculum policy, I have found a set of educational implications that could be drawn from the study. First of all, I have to admit that Citizenship is a flexible or vulnerable subject that very easily to be influenced by the change of national curriculum policy and social political status quo. Although the subject along with its teacher education seems missing "a golden age from 1998 to 2010" (Davies \& Chong, 2016), the case study showcases a university's persistence in promoting teacher education for citizenship, which re-demonstrates multiple tensions in the field of citizenship education (Osler \& Starkey, 2005). In such a changing period, the university-led training approach provides classical, fundamental and profound academic knowledge and underlying values, which might be necessary for teachers to overcome challenges.

Secondly, enlightened by researchers, teachers and participants in UCL-IOE's case programmes, I call for a broader perspective to understand citizenship education and teacher education. Due to its close relation to everyday social and political life, citizenship has reached multiple levels of programmes at UCL-IOE beyond in-service teacher training. The student teachers and students who have not yet planned to become teacher have also been welcomed to the citizenship-related programmes, being engaged in a practical and creative way. In other words, the programmes could contribute to supporting current teachers and preparing future teachers. 
Thirdly, some case programmes have broken the subject boundary in order to develop a cross-subject and interdisciplinary training. Just as The Crick Report (QCA, 1998) and National Curriculum frameworks addressed, citizenship education needs wisdom and solutions from other subjects. UCL-IOE's examples sufficiently present that citizenship contains knowledge and skills that could be and should be transferable in multiple subjects. The university-led training programmes have a great advantage in organising interdisciplinary cooperation and collaboratively learning for teachers. This approach may arouse some teachers' potential interest and competence to work in the field of citizenship education so that they would bring different perspectives of understanding and more creative solutions towards teaching citizenship in schools.

Finally, a good teacher education programme must require teachers' participation in education practice, to put academic theories into different education settings. Although UCL-IOE is specialised in providing university-led approach of teacher education, it extremely encourages and pursues for good cooperation with other organisations. For instance, the university-led PGCE programme works together with the School Direct PGCE programmes, cooperatively arranging students' school placement. The GCP-ACS programme has established networks and obtained support from NGOs, which ensures students' placement and campaigning under the guide of NGOs, encouraging cooperation with non-teacher participants. These strategies would help students to better understand the nature of citizenship education in practice and how active and responsible citizenship could and should be nurtured.

To sum up, this case study presents that the framework of National Curriculum for Citizenship has gone through several versions due to social, political and pedagogical changes, however, a model of university-based teacher education remains committed to develop the subject and the field. The study also reflects on the author's experience working as both participant researcher and teaching staff in the programmes. The paper has analysed a relatively comprehensive and professional structure for training teachers in Citizenship Education, which consists of fundamental education, specialised education and practice-driven education cooperating with schools and social organisations. I conclude that a high-quality teacher education for citizenship must help both pre-service and in-service teachers to develop subject-based, pedagogical and transferable competence. A school is never an isolated island, 
but connected with developing society and technology, so does the university. Therefore, teacher education for Citizenship need to engage a wider range of support and cooperation so that it inspires teachers' agency and further participation.

\section{Acknowledgements}

1. I am very grateful for all the support from my research supervisor, Professor Hugh Starkey at UCL-IOE, who has worked as a programme leader of EVS, TPDE, TL-Citizenship \& PSHEE, MA Citizenship and GCP-ACS and also participated teaching in PGCE Citizenship and other related programmes. He offers me with opportunity to be engaged in teaching and research into such a field. Great thanks to all teachers, facilitators, students and NGOs who support the teaching and learning over the years, particularly to Dr. Mai Abu Moghli, Dr. Kerim Sen, Dr. Ioanna Noula and Dr. Anielka Pieniazek, who worked with me in the programmes and provided kind and generous help.

2. This paper is a product of comparative study contributing to the Chinese national research project "The Integration of Moral and Citizenship Curricula through elementary and higher education", which is one of sub-projects of "The Development of Chinese Traditional Cultural Studies through Teaching Innovation" (Project Number: VFA18003) funded by 2018 National Social Sciences Foundation for Significant Education Project.

[本研究系2018年度国家社会科学基金教育学重大课题 “教材建设中创新性 发展中华优秀传统文化研究(VFA18003)” 之子课题 “大中小德育课程一体 化研究” 的比较研究成果]

\section{References}

Andrews, R., \& Mycock, A. (2007). Citizenship Education in the UK: Devolution, Diversity and Divergence. Citizenship Teaching and Learning, 3(1), 73-88.

Arthur, J., Davies, I., \& Hahn, C. (Eds.). (2008). The SAGE Handbook of Education for Citizenship and Democracy. London: SAGE Publications.

Benton, T., Cleaver, E., Featherstone, G., et al. (2008). Citizenship Education Longitudinal Study (CELS): Sixth Annual Report. Young People's Civic Participation In and Beyond School: Attitudes, Intentions and Influences (dcsf Research Report 052). London: DCSF.

Brimi, H. (2009). Academic Instructors or Moral Guides? Moral Education in America and the Teacher's Dilemma. The Clearing House, 82(3), 125-130. 
Cleaver, E., Ireland, E., Kerr, D., et al. (2005). Citizenship Education Longitudinal Study: Second Cross-Sectional Survey 2004. Listening to Young People: Citizenship Education in England (DfES Research Report 626). London: DfES.

Darling-Hammond, L. (1998). Teachers and Teaching: Testing Hypotheses from a National Commission Report. Educational Researcher, 27(1), 5-15.

Davies, I., \& Chong, E. (2016). Current Challenges for Citizenship Education in England. Asian Education and Development Studies, 5(1), 20-36. doi: 10.1108/AEDS-05 -2015-0015.

DfE. (2013). Citizenship Programmes of Study: Key Stages 3 and 4 (National Curriculum in England). London: Department for Education. Retrieved from https://www .gov.uk/government/uploads/system/uploads/attachment_data/file/239o6o/ SECONDARY_national_curriculum_-_Citizenship.pdf.

DfE. (2015). Citizenship Programmes of Study: Key Stages 1 and 2 (National Curriculum in England). London: Department for Education. Retrieved from https://www .gov.uk/government/uploads/system/uploads/attachment_data/file/402173/ Programme_of_Study_KS1_and_2.pdf.

DfE. (2018). Get into Teach. Department for Education. Retrieved from https:// getintoteaching.education.gov.uk.

DfEE, \& QCA. (1999). Citizenship: The National Curriculum for England (Key Stages 3-4). London: Department for Education and Employment \& Qualification and Curriculum Authority. Retrieved from https://www.education.gov.uk/publications/eOrderingDownload/QCA-99-470.pdf.

Drinkwater, M., Rizvi, F., \& Edge, K. (2019). Transnational Perspectives on Democracy, Citizenship, Human Rights and Peace Education. London: Bloomsbury.

Heater, D. (2001). The History of Citizenship Education in England. Curriculum Journal, 12(1), 103-123. doi: 10.1080/09585170122713.

Heater, D. (2002). The History of Citizenship Education: A Comparative Outline. Parliamentary Affairs, 55(3), 457-474.

Ireland, E., Kerr, D., Lopes, J., et al. (2006). Active Citizenship and Young People: Opportunities, Experiences and Challenges In and Beyond School Citizenship Education Longitudinal Study: Fourth Annual Report (DfES Research Report 732). London: DfES.

Keating, A., Kerr, D., Benton, T., et al. (2010). Citizenship Education In England 2001-2010: Young People's Practices And Prospects For The Future: The Eighth and Final Report From The Citizenship Education Longitudinal Study (cels) (DfES Research Report 059). London: DfES.

Keating, A., Kerr, D., Lopes, J., et al. (2009). Embedding Citizenship Education in Secondary Schools in England (2002-08): Citizenship Education Longitudinal Study Seventh Annual Report (DCSF Research Report 172). London: DCSF.

Kerr, D., Cleaver, E., Ireland, E., et al. (2003). Citizenship Education Longitudinal Study: First Cross-sectional Survey. 2001-2002. (DfES Research Report 416). London: DfES. 
Kerr, D., Ireland, E., Lopes, J., et al. (2004). Making Citizenship Real. Citizenship Education Longitudinal Study: Second Annual Report. First Longitudinal Survey (DfES Research Report 531). London: DfES.

Kerr, D., Lopes, J., Nelson, J., et al. (2007). VISION versus PRAGMATISM: Citizenship in the Secondary School Curriculum in England. Citizenship Education Longitudinal Study: Fifth Annual Report (DfES Research Report 845). London: DfES.

Osler, A., \& Starkey, H. (2005). Changing Citizenship: Democracy and Inclusion in Education. Maidenhead: Open University Press.

Osler, A., \& Starkey, H. (2010). Teachers and Human Rights Education. Stoke-on-Trent: Trentham.

Print, M., \& Smith, A. (2001). Teaching Civic Education For a Civil, Democratic Society in The Asian Region. Asia-Pacific Education Review, 1(1), 101-109.

QCA. (1998). Education for Citizenship and the Teaching of Democracy in Schools (The Crick Report). London: Qualification and Curriculum Authority.

QCA. (2001). Citizenship: A scheme of work for key stage 3 (Teacher's guide). London: Qualification and Curriculum Authority.

QCA. (2007a). Citizenship: Programme of Study for Key Stage 3 and Attainment Target. Qualification and Curriculum Authority. http://www.education.gov.uk/schools/ teachingandlearning/curriculum/secondary/boo199157/citizenship/ks3.

QCA. (2007b). Citizenship: Programme of Study for Key Stage 4 and Attainment Target. Qualification and Curriculum Authority. http://www.education.gov.uk/schools/ teachingandlearning/curriculum/secondary/boo199157/citizenship/ks4.

Starkey, H. W. (2018). Fundamental British Values and Citizenship Education: tensions between national and global perspectives. 100 (2). Geografiska Annaler: Series B, Human Geography, 100(2), 149-162. doi: 10.1080/04353684.2018.1434420.

UCL-IOE. (2010). Transnational Perspectives on Democratic Education (An Introduction to the Course). London: Institute of Education, University College London.

UCL-IOE. (2011). Teaching and Learning of Citizenship and PSHEE: Assessment Portfolio and Course Handbook 2011/2012. London: Institute of Education, University College London.

UCL-IOE. (2013). Education, Values and Society: Module Handbook and Course Readings. London: Institute of Education, University College London.

UCL-IOE. (2014). Education, Values and Society: Module Handbook and Course Readings. London: Institute of Education, University College London.

UCL-IOE. (2016). Active Citizenship Strand Overview. London: Institute of Education, University College London.

UCL-IOE. (2017). Active Citizenship Strand Overview. London: Institute of Education, University College London.

UCL-IOE. (2018a). Education Citizenship MA 2019/20 ENTRY (Programm Guidance). London: Institute of Education, University College London. Retrieved from https:// ucl.reportlab.com/media/g/education-citizenship-ma.pdf. 
UCL-IOE. (2018b). PGCE Citizenship (Programm Introduction). London: Institute of Education, University College London. Retrieved from https://www.ucl.ac.uk/ioe/ courses/teacher-training/citizenship-pgce.

UCL-IOE. (2019). Transnational Perspectives on Democratic Education (An Introduction to the Course). London: Institute of Education, University College London.

Unesco. (1998). Citizenship Education for the 21st Century. Paris: United Nations Educational, Scientific and Cultural Organization. 